\title{
ANALISIS DINAMIK MODEL PENDANGKALAN DANAU LIMBOTO DENGAN PEMBERSIHAN ECENG GONDOK DAN PENGERUKAN ENDAPAN
}

\section{Dynamical Analysis of mathematical Model of Limboto Lake Silting with Water Hyacinth Cleaning Solution}

\author{
Sri Lestari Mahmud ${ }^{1 *}$, Novianita Achmad ${ }^{2}$ \\ ${ }^{1,2}$ Prodi Matematika, Fakultas MIPA, Universitas Negeri Gorontalo
}

Jl. Prof. Dr. Ing. B. J. Habibie, Moutong, Tilongkabila, Kab.Bone Bolango, Gorontalo 96119, Indonesia

e-mail: 1*sri.lestari@ung.ac.id; 22usmanita2000@yahoo.com ;

Corresponding author*

\begin{abstract}
Abstrak
Artikel ini membahas tentang model matematika pendangkalan danau Limboto dengan solusi pembersihan eceng gondok. Pemodelan diawali dengan mengkonstruksi model berdasarkan faktorfaktor yang mempengaruhi pendangkalan yang kemudian dibentuk menjadi sebuah sistem persamaan diferensial orde satu. Selanjutnya model di analisis dengan mecari titik kesetimbangan dan kestabilan. Untuk melihat kondisi pendangkalan danau berdasarkan kondisi kestabilan dilakukan simulasi numerik. Hasil simulasi menunjukkan bahwa dengan adanya pembersihan eceng gondok, maka kondisi danau akan terjaga eksistensinya yang ditandai dengan bertambahnya volume danau Limboto, meskipun tetap terjadi pengurangan volume akibat adanya endapan dan nutrien yang berasal dari sungai.
\end{abstract}

Kata Kunci : Model matematika, pendangkalan, eceng gondok

\begin{abstract}
This article discusses about mathematical model of Limboto lake silting with water hyacinth cleaning solution. Modelling begins with constructing a model based on the factors that affect silting which is then formed into a system of first order differential equations. Furthermore, the model is analyzed by looking for equilibrium and stability. To see the condition of lake silting based on the stability condition, a numerical simulation was performed. The simulation results show that with water hyacinth cleaning, the lake will maintain its existence, which is indicated by an increase the Limboto lake volume, although there is still a decrease in volume due to the presence of sediment and nutrients from the river.
\end{abstract}

Keywords: mathematical model, Siltation, water hyacinth 


\section{PENDAHULUAN}

Danau Limboto adalah salah satu aset sumberdaya alam yang dimiliki Provinsi Gorontalo saat ini. Areal danau ini berada pada dua wilayah yaitu $\pm 30 \%$ wilayah kota Gorontalo dan $\pm 70 \%$ di wilayah Kabupaten Gorontalo dan menjangkau 5 kecamatan. Air yang masuk ke danau Limboto bersumber dari air hujan yang langsung jatuh ke danau dan air yang berasal dari sungai-sungai yang masuk ke danau. Sungai-sungai yang mengalir dan bermuara ke Danau Limboto terdapat sebanyak 23 sungai diantaranya Aloe, Marisa, Meluopo, Biyonga, Bulota, Talubongo, Bolango, Pohu, Ritenga dan sungai Topodu [1], [2].

Danau Limboto merupakan bagian penting dari ekosistem perairan yang berfungsi sebagai tempat hidup organisme dan pengatur fungsi hidrologi. Saat ini, fungsi danau Limboto sudah tidak berjalan sebagaimana mestinya karena adanya masalah penyusutan luas dan pendangkalan danau. Menurut Kementrian Lingkungan Hidup, danau Limboto termasuk kategori danau kritis. Hal tersebut dikarenakan penyusutan yang terus terjadi di danau Limboto yang mengancam keberlanjutan dari danau tersebut [3]. Berdasarkan data yang diperoleh dari BALIHRISTI bahwa pada tahun 1932 rata-rata kedalaman Danau Limboto 30 meter dengan luas $7.000 \mathrm{Ha}$, dan tahun 1961 rata-rata kedalaman Danau berkurang menjadi 10 meter dan luas menjadi 4.250 Ha. Sedangkan tahun 1990 - 2008 kedalaman Danau Limboto rata-rata tinggal 2,5 meter dengan luas $3.000 \mathrm{Ha}$. [4].

Penyebab utama dari pendangkalan danau Limboto adalah sedimentasi, baik sedimen yang berasal dari sungai maupun sedimen yang berasal dari aktivitas manusia di danau [5]. Penyebab lainnya dari pendangkalan danau Limboto adalah pertumbuhan eceng gondok yang berlebihan atau tidak terkendali. Selain itu, sisa-sisa tumbuhan yang ada pada perairan lama-kelamaan akan mengalami proses pembusukan dan akan mengendap pada dasar perairan [6]. Hal tersebut, jika terus terjadi secara berkelanjutan dapat menimbulkan penumpukan sisa-sisa tanaman dan sangat dikhawatirkan dapat merusak ekosisitem danau.

Penelitian tentang model matematika pendangkalan danau Limboto, sudah pernah dilakukan oleh Mahmud,dkk [7]. Dalam penelitian tersebut dikonstruksi model matematika pendangkalan danau Limboto berdasarkan faktor-faktor yang mempengaruhi pendangkalan danau tersebut. Selain itu, ada tambahan parameter yang merupakan solusi dari permasalahan pendangkalan dalam model yaitu pengerukan endapan. Hasil penelitian menunjukan bahwa dengan adanya pengerukan endapan, volume dari danau dapat dijaga eksistensinya, meskipun terjadi pengurangan volume akibat adanya endapan dan eceng gondok. Pada penelitian ini, diperkenalkan model baru yang mengacu pada model [7] dengan modifikasi berupa penambahan parameter yakni pembersihan eceng gondok. Penambahan parameter pembersihan eceng gondok merupakan salah satu hal yang penting dalam model ini karena sebagaimana yang telah dijelaskan sebelumnya bahwa salah satu penyebab utama dalam pendangkalan adalah banyaknya eceng gondok yang tumbuh di danau Limboto. Populasi eceng gondok yang berlebihan menyebabkan pengurangan daya tampung air di danau serta menyebabkan kehilangan air, karena proses evapotranspirasi yang berlebihan [8]. Jika hal ini terjadi maka akan menyebabkan terjadinya kerusakan ekosistem danau, sehingga hal ini menjadi faktor penting pembersihan eceng gondok ditambahkan sebagai parameter baru dalam model.

Penelitian tentang model matematika pendangkalan danau Limboto, sudah pernah dilakukan oleh Mahmud,dkk [9]. Pemodelan matematika merupakan salah satu teknik untuk merepresentasikan suatu sistem yang kompleks ke dalam model matematika. [9]. Dengan memodelkan pendangkalan danau dengan solusi pembersihan eceng gondok diharapkan diharapakan dapat menjadi salah satu solusi untuk menekan laju pendangkalan danau Limboto, sehingga hal ini dapat menghindarkan danau Limboto untuk tidak menjadi daratan

\section{METODE PENELITIAN}

Tahapan yang dilakukan dalam mengkonstruksi model pendangkalan danau Limboto yakni sebagi berikut:

a) Merumuskan asumsi-asumsi dan menerjemahkannya dalam bahasa matematika.

b) Menetapkan dan membatasi parameter-parameter yang memberikan perubahan terhadap variabelvariabel yang ada.

c) Mengkonstruksi model matematika pendangkalan danau Limboto dengan solusi pembersihan eceng gondok dalam suatu sistem persamaan diferensial orde satu.

d) Mempelajari dinamika dari model dengan mengidentifikasi eksistensi titik kesetimbangan dan kestabilannya.

e) Memberikan simulasi numerik untuk memberikan interpretasi geometris terhadap hasil analisis dinamik yang dilakukan dengan menggunakan skema numerik Runge-Kutta orde-4. 


\section{HASIL DAN PEMBAHASAN}

\subsection{Model Matematika}

Model dasar pendangkalan danau Limboto telah dikonstruksi oleh Mahmud, dkk [7]. Variabel yang digunakan dalam model merupakan faktor-faktor yang diasumsikan memberikan pengaruh terbesar terhadap pendangkalan danau Limboto. Faktor-faktor yang merupakan variabel dalam model tersebut secara matematis dapat dilihat pada Tabel 1.

Tabel 1. Faktor-faktor yang mempengaruhi pendangkalan danau Limboto dan penyimbolannya

\begin{tabular}{clc}
\hline Variabel & \multicolumn{1}{c}{ Interpretasi } & Satuan \\
\hline $\boldsymbol{x}(\boldsymbol{t})$ & kepadatan populasi eceng gondok pada waktu $t$ & volume $\left(\mathrm{m}^{3}\right)$ \\
\hline $\boldsymbol{y}(\boldsymbol{t})$ & jumlah nutrien di danau pada waktu $t$ & volume $\left(\mathrm{m}^{3}\right)$ \\
\hline $\boldsymbol{u}(\boldsymbol{t})$ & jumlah endapan di danau pada waktu $t$ & volume $\left(\mathrm{m}^{3}\right)$ \\
\hline $\boldsymbol{v}(\boldsymbol{t})$ & volume danau pada waktu $t$ & volume $\left(\mathrm{m}^{3}\right)$ \\
\hline $\boldsymbol{t}$ & Waktu & detik, menit, tahun, dan \\
sebagainya
\end{tabular}

Pada penelitian ini, model dimodifikasi dengan menambahkan parameter yakni pembersihan eceng gondok $(H)$ pada populasi $x(t)$. Laju perubahan kepadatan populasi eceng gondok $x(t)$ di danau Limboto dipengaruhi oleh jumlah nutrien, volume danau, proteksi lingkungan yang diterimanya dan solusi berupa pembersihan eceng gondok dipermukaan danau. Laju perubahan jumlah nutrien $y(t)$ dipengaruhi oleh jumlah nutrien yang dibawa oleh air sungai ke danau, jumlah nutrien yang dibawa oleh sungai dari air danau ke laut, jumlah nutrien yang dihasilkan dari pembudidayaan ikan yang tidak ramah lingkungan, dan jumlah nutrien yang diserap oleh eceng gondok. Laju perubahan jumlah endapan $u(t)$ dipengaruhi oleh jumlah endapan yang dibawa oleh air sungai ke danau dan jumlah endapan yang dibawa oleh sungai dari air danau ke laut. Laju perubahan volume danau $v(t)$ bergantung pada laju pengerukan danau, laju konversi eceng gondok yang mati menjadi endapan, dan penyatuan endapan di air dengan dasar danau.

Beberapa asumsi yang digunakan dalam model ini yakni sebagai berikut :

1. Tanaman pengganggu yang diperhitungkan hanyalah eceng gondok sedangkan yang lainnya tidak, sebab sebagian besar dari tanaman pengganggu yang ada di danau Limboto adalah eceng gondok.

2. Eceng gondok tumbuh secara logistik

3. Nutrien yang masuk ke danau melalui air sungai, berasal dari limbah rumah tangga dan limbah pertanian.

4. Penambahan endapan yang berasal dari pembudidayaan ikan yang tidak ramah lingkungan adalah konstan.

5. Volume air yang masuk dan keluar dari danau sama.

Berdasarkan penjelasan diatas dapat dikonstruksi model matematika pendangkalan danau Limboto dengan dengan solusi berupa pembersihan eceng gondok yang didefinisikan oleh sistem persamaan diferensial yaitu :

$$
\begin{aligned}
& \frac{d x}{d t}=r x\left(1-\frac{x}{\alpha y+\beta v+\omega}\right)-\mathrm{Hx} \\
& \frac{d y}{d t}=\left(\kappa_{1}+\kappa_{2}+\kappa_{3}\right) \sigma-\frac{\delta y}{v}+\eta v-\xi y \\
& \frac{d u}{d t}=\left(\zeta_{1}+\zeta_{2}+\zeta_{3}\right) \sigma-\frac{\delta u}{v} \\
& \frac{d v}{d t}=\Lambda-u-\gamma x
\end{aligned}
$$

Adapun parameter yang digunakan pada persamaan (1) dapat dilihat pada Tabel 2, berikut: 
Tabel 2. Deskripsi Parameter pada Model Pendangkalan Danau Limboto

\begin{tabular}{|c|c|c|}
\hline Parameter & Interpretasi & Satuan \\
\hline $\boldsymbol{r}$ & laju pertumbuhan intrinsik eceng gondok & $\%$ / hari \\
\hline$\alpha$ & $\begin{array}{l}\text { konstanta daya dukung lingkungan eceng } \\
\text { gondok oleh nutrien }\end{array}$ & $\%$ \\
\hline $\boldsymbol{\beta}$ & $\begin{array}{l}\text { konstanta daya dukung lingkungan eceng } \\
\text { gondok oleh volume danau }\end{array}$ & $\%$ \\
\hline$\omega$ & proteksi lingkungan (makanan lain) & $m^{3}$ \\
\hline $\boldsymbol{H}$ & Laju pembersihan eceng gondok & $m^{3} /$ hari \\
\hline$\kappa_{1}$ & $\begin{array}{l}\text { konsentrasi nutrien yang dibawa oleh sungai } \\
\text { akibat limbah rumah tangga }\end{array}$ & $\%$ \\
\hline$\kappa_{2}$ & $\begin{array}{l}\text { konsentrasi nutrien dibawa oleh sungai dari erosi } \\
\text { akibat penebangan hutan }\end{array}$ & $\%$ \\
\hline$\kappa_{3}$ & $\begin{array}{l}\text { konsentrasi nutrien dibawa oleh sungai dari areal } \\
\text { persawahan }\end{array}$ & $\%$ \\
\hline$\sigma$ & laju air sungai yang masuk ke danau & $m^{3} /$ hari \\
\hline$\delta$ & laju air danau ke laut melalui sungai & $m^{3} /$ hari \\
\hline $\boldsymbol{\eta}$ & $\begin{array}{l}\text { konsentrasi nutrien di danau akibat } \\
\text { pembudidayaan ikan yang tidak ramah } \\
\text { lingkungan }\end{array}$ & $\% /$ hari \\
\hline$\xi$ & $\begin{array}{l}\text { konsentrasi nutrien yang diserap oleh eceng } \\
\text { gondok }\end{array}$ & $\%$ / hari \\
\hline$\zeta_{1}$ & $\begin{array}{l}\text { konsentrasi endapan yang dibawa oleh sungai } \\
\text { akibat limbah rumah tangga }\end{array}$ & $\%$ \\
\hline$\zeta_{2}$ & $\begin{array}{l}\text { konsentrasi endapan yang dibawa oleh sungai } \\
\text { dari erosi akibat penebangan hutan }\end{array}$ & $\%$ \\
\hline$\zeta_{3}$ & $\begin{array}{l}\text { konsentrasi endapan yang dibawa oleh sungai } \\
\text { dari areal persawahan }\end{array}$ & $\%$ \\
\hline$\Lambda$ & laju pengerukan danau & $m^{3} /$ hari \\
\hline$\gamma$ & $\begin{array}{l}\text { laju pertambahan endapan di danau akibat } \\
\text { kematian dari eceng gondok }\end{array}$ & $m^{3} /$ hari \\
\hline
\end{tabular}

Sumber: [7]

\subsection{Penentuan Titik Kesetimbangan}

Untuk menentukan titik kesetimbangan [10] model (1), dapat dicari dengan menyelesaikan sistem persamaan berikut :

$$
\begin{aligned}
& r x\left(1-\frac{x}{\alpha y+\beta v+\omega}\right)-\mathrm{Hx}=0 \\
& \left(\kappa_{1}+\kappa_{2}+\kappa_{3}\right) \sigma-\frac{\delta y}{v}+\eta v-\xi y=0 \\
& \left(\zeta_{1}+\zeta_{2}+\zeta_{3}\right) \sigma-\frac{\delta u}{v}=0 \\
& \Lambda-u-\gamma x=0
\end{aligned}
$$

dari persamaan pertama di model (1), diperoleh diperoleh $x=0$ atau $x=\frac{(r-H)(\alpha y+\beta v+\omega)}{r}$. Jika $x=0$ maka diperoleh titik kesetimbangan pertama

$$
T_{1}=\left(0, \frac{\left(\kappa_{1}+\kappa_{2}+\kappa_{3}\right) \sigma \bar{v}+\eta \bar{v}^{2}}{\delta+\xi \bar{v}}, \Lambda, \bar{v}\right)
$$

dengan $\bar{v}=\frac{\delta \Lambda}{(\zeta 1+\zeta 2+\zeta 3) \sigma}$. Titik $T_{1}$ merupakan titik kesetimbangan bebas eceng gondok. Jelas bahwa $T_{1} \in$ $\mathbb{R}_{+}^{4}$. Selanjutnya untuk $x=\frac{(r-H)(\alpha y+\beta v+\omega)}{r}, x>0$ jika $r>H$. Dari nilai $x$ tersebut diperoleh titik kesetimbangan $T_{2}$ yakni :

$$
T_{2}=\left(x^{*}, y^{*}, u^{*}, v^{*}\right)
$$


dimana

$$
\begin{aligned}
x^{*} & =\frac{1}{\gamma}\left(\Lambda-\frac{\left(\zeta_{1}+\zeta_{2}+\zeta_{3}\right) \sigma v^{*}}{\delta}\right) \\
y^{*} & =\frac{1}{\alpha}\left(\frac{\left(\zeta_{1}+\zeta_{2}+\zeta_{3}\right) r \sigma v^{*}}{(r-H) \gamma \delta}+\beta v^{*}+\omega\right)-\frac{\Lambda \mathrm{r}}{(r-H) \alpha \gamma} \\
u^{*} & =\frac{\left(\zeta_{1}+\zeta_{2}+\zeta_{3}\right) \sigma v^{*}}{\delta}
\end{aligned}
$$

dan $v^{*}$ adalah solusi adalah solusi positif dalam $v^{*}$ dari polinom $a_{1} v^{2}-a_{2} v+a_{3}=0$ dengan

$$
\begin{aligned}
& a_{1}=\eta+\frac{\beta \xi}{\alpha}+\frac{\left(\zeta_{1}+\zeta_{2}+\zeta_{3}\right) \sigma \xi r}{(r-H) \alpha \gamma \delta} \\
& a_{2}=\left(\left(\kappa_{1}+\kappa_{2}+\kappa_{3}\right) \sigma+\frac{\left(\zeta_{1}+\zeta_{2}+\zeta_{3}\right) \sigma r}{(r-H) \alpha \gamma}+\frac{\beta \delta}{\alpha}+\frac{\xi \omega}{\alpha}\right)-\frac{\Lambda \xi r}{(r-H) \alpha \gamma} \\
& a_{3}=\frac{\delta \omega}{\alpha \gamma}-\frac{r \delta \Lambda}{(r-H) \alpha \gamma}
\end{aligned}
$$

Titik kesetimbangan $T_{2}$ merupakan titik kesetimbangan interior dimana seluruh variabel eksis secara biologis. Ketika $y^{*}=0$ mengakibatkan titik kesetimbangan interior tidak eksis secara biologis, sehingga kita asumsikan $y^{*}>0$ atau $\Lambda<\left(\frac{\left(\zeta_{1}+\zeta_{2}+\zeta_{3}\right) r \sigma v^{*}}{(r-H) \gamma \delta(r-H) \alpha \gamma}+\beta v^{*}+\omega\right) \frac{(r-H) \gamma}{r}$. Syarat eksistensi dari titik kesetimbangan $T_{2}$ dapat dilihat dari teorema berikut :

Teorema 1. Misalkan

$\Lambda<\frac{(r-H) \gamma}{r} \min \left\{\left(\frac{\left(\zeta_{1}+\zeta_{2}+\zeta_{3}\right) r \sigma v^{*}}{(r-H) \gamma \delta(r-H) \alpha \gamma}+\beta v^{*}+\omega\right),\left(\left(\kappa_{1}+\kappa_{2}+\kappa_{3}\right) \sigma+\frac{\left(\zeta_{1}+\zeta_{2}+\zeta_{3}\right) \sigma r}{(r-H) \alpha \gamma}+\frac{\beta \delta}{\alpha}+\frac{\xi \omega}{\alpha}\right) \frac{\alpha}{\xi}, \frac{\omega}{\gamma}\right\}$

1. Jika $a_{2}^{2}<4 a_{1} a_{3}$ maka tidak ada titik kesetimbangan di interior dari model (1)

2. Jika $a_{2}^{2}=4 a_{1} a_{3}$ maka ada satu titik kesetimbangan di interior dari model (1)

3. Jika $a_{2}^{2}>4 a_{1} a_{3}$ maka ada dua titik kesetimbangan di interior dari model (1)

Bukti. Perhatikan bahwa $a_{1}$ selalu positif.

Ketika $\Lambda<\frac{(r-H) \gamma}{r} \min \left\{\left(\frac{\left(\zeta_{1}+\zeta_{2}+\zeta_{3}\right) r \sigma v^{*}}{(r-H) \gamma \delta(r-H) \alpha \gamma}+\beta v^{*}+\omega\right),\left(\left(\kappa_{1}+\kappa_{2}+\kappa_{3}\right) \sigma+\frac{\left(\zeta_{1}+\zeta_{2}+\zeta_{3}\right) \sigma r}{(r-H) \alpha \gamma}+\frac{\beta \delta}{\alpha}+\frac{\xi \omega}{\alpha}\right) \frac{\alpha}{\xi}, \frac{\omega}{\gamma}\right\}$ maka akibatnya $\mathrm{x}^{*}, \mathrm{y}^{*}, \mathrm{u}^{*}, a_{2}, a_{3}>0$. Dengan demikian, eksistensi dari titik kesetimbangan $T_{2}$ bergantung pada nilai $\mathrm{v}^{*}$. Karena $\mathrm{v}^{*}$ adalah solusi positif dari polinom $a_{1} v^{2}-a_{2} v+a_{3}=0$ maka diperoleh :

$$
v_{1}^{*}=\frac{a_{2}+\sqrt{a_{2}^{2}-4 a_{1} a_{3}}}{2 a_{1}} \quad v_{2}^{*}=\frac{a_{2}-\sqrt{a_{2}^{2}-4 a_{1} a_{3}}}{2 a_{1}}
$$

Jika $a_{2}^{2}<4 a_{1} a_{3}$ maka $v_{1,2}^{*} \in \mathbb{C}$ sehingga $T_{2} \notin \mathbb{R}^{4}$. Jelas bahwa tidak ada titik kesetimbangan di interior dari model (1). Jika $a_{2}^{2}=4 a_{1} a_{3}$ maka diperoleh $v^{*}=\frac{a_{2}}{2}$. Karena $a_{2}>0$ maka $v^{*}>0$ sehingga jelas hanya ada satu titik kesetimbangan interior. Selanjutnya untuk syarat $a_{2}^{2}>4 a_{1} a_{3}$ maka $v_{1,2}^{*} \in \mathbb{R}$. Jelas untuk kondisi ini $v_{1}^{*}=\frac{a_{2}+\sqrt{a_{2}^{2}-4 a_{1} a_{3}}}{2 a_{1}}>0$. Untuk $v_{2}^{*}=\frac{a_{2}-\sqrt{a_{2}^{2}-4 a_{1} a_{3}}}{2 a_{1}}$, titik kesetimbangan ini ada jika $a_{2}>\sqrt{a_{2}^{2}-4 a_{1} a_{3}}$. Karena $\Lambda<\frac{\omega}{\gamma}$ mengakibatkan $a_{3}>0$ sehingga syarat $a_{2}>\sqrt{a_{2}^{2}-4 a_{1} a_{3}}$ terpenuhi. Dengan demikian terdapat dua titik kesetimbangan di interior dari model (1).

Berdasarkan Teorema 1, dapat terlihat bahwa eksistensi dari danau sangat bergantung pada laju pengerukan danau $(\Lambda)$ dan laju pembersihan eceng gondok $(H)$. Secara biologis hal ini masuk akal, karena dengan semakin banyaknya endapan yang dikeluarkan dari danau melalui pengerukan maka akan semakin bertambah pula volume danau. Sama halnya dengan pembersihan eceng gondok, semakin banyak eceng gondok yang dibersihkan dipermukaan danau, maka akan semakin sedikit peluang endapan bertambah sehingga ini akan dapat menjaga eksistensi danau tersebut. Selanjutnya titik kesetimbangan model (1) akan dianalisis untuk mengidentifikasi syarat eksistensi danau. 


\subsection{Analisis Kestabilan Titik Kesetimbangan}

Pada bagian ini dilakukan pelinearan pada model (1) dengan melakukan ekspansi deret Taylor. Berdasarkan pelinearan, kita cukup mengidentifikasi nilai eigen dari matriks Jacobi model (1) di titik kesetimbangannya [10], [11] sehingga diperoleh matriks Jacobi sebagai berikut:

$$
J(x, y, u, v)=\left(\begin{array}{cccc}
-H+r-\frac{2 r x}{\alpha y+\beta v+\omega} & \frac{\alpha r x^{2}}{(\alpha y+\beta v+\omega)^{2}} & 0 & \frac{\beta r x^{2}}{(\alpha y+\beta v+\omega)^{2}} \\
0 & -\frac{\delta+v \xi}{v} & 0 & \frac{\delta y}{v^{2}}+\eta \\
0 & 0 & -\frac{\delta}{v} & \frac{\delta u}{v^{2}} \\
-\gamma & 0 & -1 & 0
\end{array}\right)
$$

Selanjutnya dengan mensubstitusi titik kesetimbangan pada matriks Jacobi (5), dilakukan identifikasi terhadap kestabilan lokal titik kesetimbangan $T_{1}$ dan $T_{2}$ yakni sebagai berikut:

Teorema 2. Titik Kesetimbangan bebas Eceng Gondok $T_{1}=\left(0, \frac{\left(\kappa_{1}+\kappa_{2}+\kappa_{3}\right) \sigma \bar{v}+\eta \bar{v}^{2}}{\delta+\xi v^{*}}, \Lambda, \bar{v}\right)$ stabil asimtotik lokal jika $r<H$ dan tidak stabil tipe pelana jika $r>H$.

Bukti. Dengan mensubtitusi titik kesetimbangan $\mathrm{T}_{1}$ ke matriks Jacobi diperoleh :

$$
J_{1}(x, y, u, v)=\left(\begin{array}{cccc}
-H+r & 0 & 0 & 0 \\
0 & -\frac{\delta}{\bar{v}}-\xi & 0 & \eta+\frac{\delta(\eta \bar{v}+(\kappa 1+\kappa 2+\kappa 3) \sigma)}{\bar{v}(\delta+\xi \bar{v})} \\
0 & 0 & -\frac{\delta}{\bar{v}} & \frac{\delta \Lambda}{\bar{v}^{2}} \\
-\gamma & 0 & -1 & 0
\end{array}\right)
$$

yang memberikan nilai eigen $\lambda_{1}=r-H, \lambda_{2}=-\frac{\delta}{\bar{v}}-\xi, \lambda_{3,4}=-\frac{1}{2 \bar{v}}\left(\delta \pm \sqrt{\delta^{2}-4 \delta \Lambda}\right)$. Dari nilai eigen yang diperoleh dapat ditentukan $\lambda_{1}<0$ jika $r<H$ dan $\lambda_{1}>0$ jika $r>H$. Begitupula untuk $\lambda_{3,4}<$ 0 jika $\delta>4 \Lambda$ dan $\operatorname{Re}\left(\lambda_{3,4}\right)<0$ jika $\delta<4 \Lambda$. Karena $\lambda_{2}<0$ dan syarat $r<H$ untuk $\lambda_{1}$ terpenuhi maka $\mathrm{T}_{1}$ stabil asimtotik lokal. Tapi jika syarat $r<H$ tidak terpenuhi maka $\mathrm{T}_{1}$ tidak stabil tipe pelana.

Berdasarkan Teorema 2, jika $r<H$ maka titik kesetimbangan $T_{1}$ stabil dan $T_{2}$ tidak eksis. Sedangkan jika $r>H$ maka $T_{1}$ tidak stabil dan $T_{2}$ stabil. Artinya jika laju pertumbuhan intrinsik eceng gondok $(r)$ lebih kecil dari laju pembersihan eceng gondok di danau $(H)$ maka hal ini akan mengakibatkan populasi eceng gondok akan punah. Sebaliknya, jika laju pertumbuhan intrinsik eceng gondok lebih besar dari laju pembersihan eceng gondok di danau maka populasi eceng gondok akan tetap ada. Ditinjau secara biologis banyak faktor-faktor yang mendukung keberadaan eceng gondok di danau. Diantaranya adalah nutrien baik yang berasal dari limbah rumah tangga maupun limbah pertanian dan pembudidayaan ikan yang tidak ramah lingkungan [12]. Oleh karena itu, kondisi yang diharapkan untuk menjaga eksistensi danau Limboto supaya tidak mengalami kepundahan yaitu dengan mengidentifikasi kondisi kesetimbangan $T_{2}$ dimana meskipun ada eceng gondok, nutrien, dan endapan, volume danau tetap bisa dipertahankan dengan melakukan pemanenan atau pembersihan eceng gondok di danau tersebut.

Teorema 3. Misalkan

$$
\begin{aligned}
& a_{1}=n+\frac{2 \delta}{v^{*}}+\xi \\
& a_{2}=\frac{n^{2} \beta \gamma}{r}+\frac{2 n \delta}{v^{*}}+n \xi+\frac{\delta\left(u+\delta+v^{*} \xi\right)}{\left(v^{*}\right)^{2}} \\
& a_{3}=\frac{1}{r\left(v^{*}\right)^{3}}\left(r u \delta\left(\delta+v^{*} \xi\right)+n r v^{*} u \delta+n r\left(v^{*}\right)^{2} \delta \xi+n r v \delta^{2}+\left(\alpha \delta y+v\left(2 \beta \delta+\alpha \eta v^{*}+\beta \xi v^{*}\right)\right) n^{2} \gamma v^{*}\right. \\
& a_{4}=\frac{\delta\left(\gamma n^{2}\left(\alpha \delta y+v^{*}\left(\alpha \eta v^{*}+\beta\left(\delta+v^{*} \xi\right)\right)\right)+n r u\left(\delta+v^{*} \xi\right)\right)}{r\left(v^{*}\right)^{3}}
\end{aligned}
$$


dengan $n=r-H$. Titik kesetimbangan interior $\mathrm{T}_{2}=\left(x^{*}, y^{*}, u^{*}, v^{*}\right)$ stabil asimtotik lokal jika $n>0$ dan $a_{1} a_{2} a_{3}>a_{3}^{2}+a_{1}^{2} a_{4}$.

Bukti. Dengan mensubtitusi titik kesetimbangan $\mathrm{T}_{2}$ ke matriks Jacobi diperoleh :

$$
J_{2}(x, y, u, v)=\left(\begin{array}{cccc}
H-r & \alpha\left(r-2 H+\frac{H^{2}}{r}\right) & 0 & \beta\left(r-2 H+\frac{H^{2}}{r}\right) \\
0 & -\frac{\delta}{v^{*}}-\xi & 0 & \frac{\delta y^{*}}{\left(v^{*}\right)^{2}}+\eta \\
0 & 0 & -\frac{\delta}{v^{*}} & \frac{\delta u^{*}}{\left(v^{*}\right)^{2}} \\
-\gamma & 0 & -1 & 0
\end{array}\right)
$$

Matriks Jacobi $J_{2}$ memiliki polinom karakteristik $\lambda^{4}+a_{1} \lambda^{3}+a_{2} \lambda^{2}+a_{3} \lambda+a_{4}$. Dengan menggunakan kriteria Routh-Hurwitz, $\mathrm{T}_{2}$ stabil asimtotik lokal jika memenuhi $a_{1}>0, a_{3}>0, a_{4}>0$, dan $a_{1} a_{2} a_{3}>$ $a_{3}{ }^{2}+a_{1}{ }^{2} a_{4}$. Karena $a_{i}>0$ untuk setiap $i=1,2,3,4$, maka $\mathrm{T}_{2}$ stabil asimtotik lokal jika memenuhi $a_{1} a_{2} a_{3}>a_{3}^{2}+a_{1}^{2} a_{4}$.

\subsection{Simulasi Numerik}

Pada bagian ini akan dilakukan simulai terhadap model (1) dengan mengggunakan software Pyhton untuk memperkuat hasil analisis dan menunjukkan kestabilan titik kesetimbangan dengan menggunakan nilai-nilai parameter pada Tabel 3. Nilai parameter yang digunakan bukan merupakan data sebenarnya karena data dilapangan belum tersedia, sehingga pemilihan parameter disesuaikan dengan kondisi kestabilan yang diperoleh pada Teorema 3 dengan mengasumsikan bahwa laju air dari sungai ke danau dan dari danau ke laut sama. Selain itu, konsentrasi nutrien dan endapan dari limbah rumah tangga, areal persawahan, dan erosi hutan sama. Dengan menggunakan nilai parameter di Tabel 3, diperoleh simulasi model seperti pada Gambar 1 .

Tabel 3. Nilai Parameter Model

\begin{tabular}{cc}
\hline Paramter & Nilai \\
\hline $\boldsymbol{r}$ & 0,8 \\
\hline $\boldsymbol{\alpha}$ & 0,7 \\
\hline $\boldsymbol{\beta}$ & 0,5 \\
\hline $\boldsymbol{\omega}$ & 0,2 \\
\hline $\boldsymbol{H}$ & 0,2 \\
\hline $\boldsymbol{\kappa}_{\mathbf{1}}$ & 0,1 \\
\hline $\boldsymbol{\kappa}_{\boldsymbol{2}}$ & 0,1 \\
\hline $\boldsymbol{\kappa}_{\mathbf{3}}$ & 0,1 \\
\hline $\boldsymbol{\sigma}$ & 0,5 \\
\hline $\boldsymbol{\delta}$ & 0,5 \\
\hline $\boldsymbol{\eta}$ & 0,1 \\
\hline $\boldsymbol{\zeta}$ & 0,1 \\
\hline $\boldsymbol{\zeta}_{\boldsymbol{1}}$ & 0,1 \\
\hline $\boldsymbol{\zeta}_{\mathbf{2}}$ & 0,1 \\
\hline $\boldsymbol{\zeta}_{\mathbf{3}}$ & 0,1 \\
\hline $\boldsymbol{\Lambda}$ & 0,7 \\
\hline $\boldsymbol{\gamma}$ & 0,2 \\
\hline
\end{tabular}



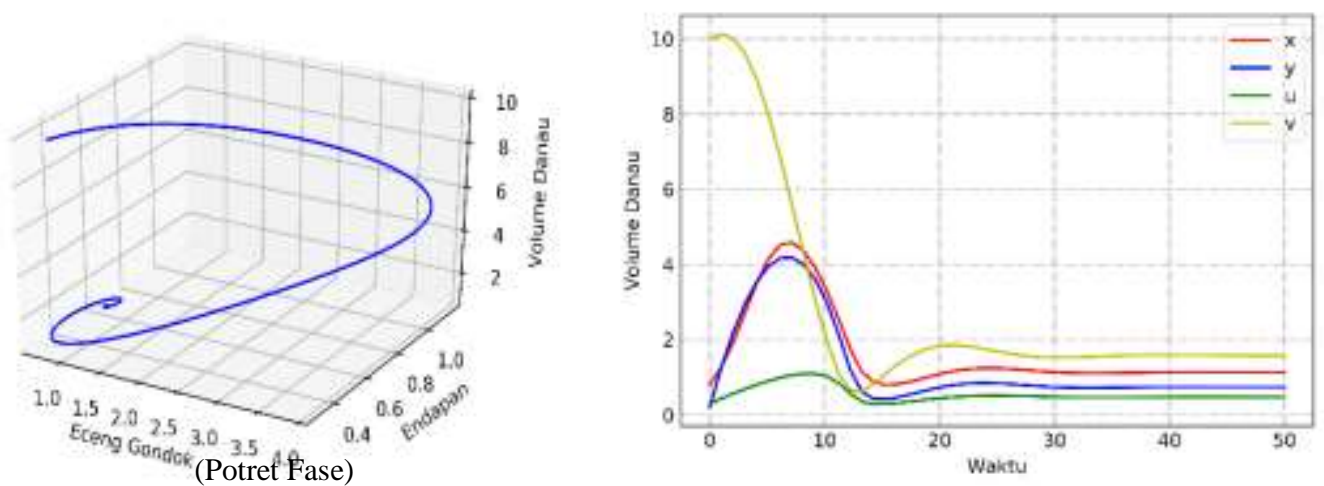

Gambar 1. Simulasi numerik dari model (1) dengan menggunakan nilai parameter pada Tabel 3

Pada tahapan ini juga, dilakukan beberapa variasi pada nilai parameter model untuk melihat perubahan: 1) Jumlah endapan yang masuk ke danau; (2) Jumlah nutrien yang masuk ke danau (3) Laju pengerukan danau dan; (4) Laju pembersihan eceng gondok.

\section{Jumlah endapan yang masuk ke danau ( $\zeta)$}

Simulasi ini dilakukan untuk melihat pengaruh jumlah endapan yang masuk ke danau terhadap eksistensi variabel lainnya, seperti yang ditunjukkan pada Gambar 2. Parameter yang digunakan sama seperti sebelumnya kecuali nilai $\zeta_{1,2,3}$ yang dinaikan menjadi 0.5 .

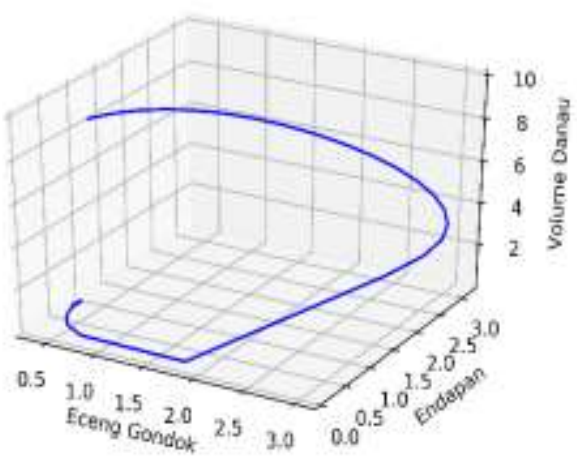

(Potret Fase)

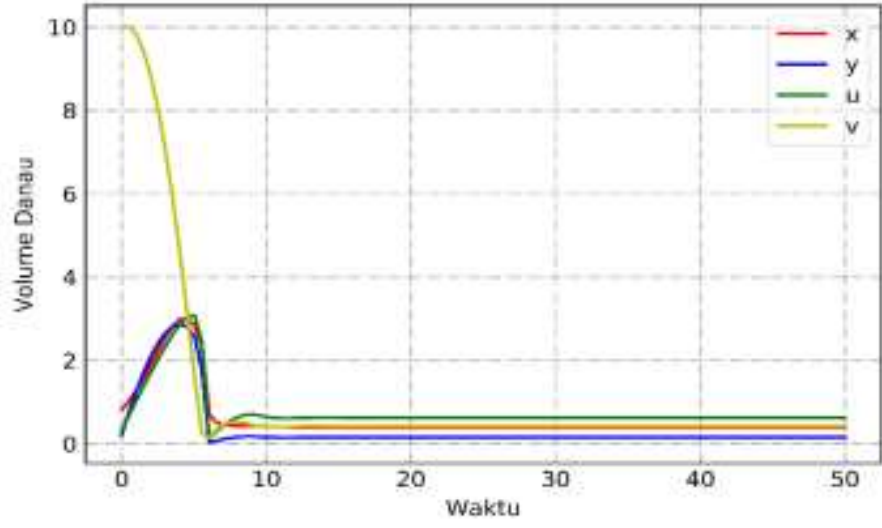

(Deret Waktu)

Gambar 2. Simulasi numerik model (1) menggunakan nilai parameter pada Tabel 3 dan $\zeta_{1}, \zeta_{2}, \zeta_{3}=0.5$

Gambar 2 menunjukkan bahwa jika laju endapan yang masuk ke danau meningkat maka jumlah populasi eceng gondok, nutrien dan volume danau berkurang, dengan tingkat konvergensinya meningkat. Hal ini sesuai fakta bahwa ketika endapan di danau semakin banyak lama kelamaan endapan tersebut akan mengeras dan menyatu dengan dasar danau sehingga menyebabkan volume danau berkurang [13]. Selain itu populasi eceng gondok berkurang karena daya dukungnya berupa nutrisi dan volume danau telah berkurang.

\section{Jumlah nutrien yang masuk ke danau ( $\kappa)$}

Pada simulasi ini, akan dilihat pengaruh jumlah nutrient yang masuk ke danau ketika jumlah nutiriennya dinaikkan sebesar $\boldsymbol{\kappa}_{\mathbf{1}}, \boldsymbol{\kappa}_{\mathbf{2}}, \boldsymbol{\kappa}_{\mathbf{3}}=\mathbf{0}, \mathbf{5}$ dengan nilai parameter lainnya tetap. Berdasarkan Gambar 3 diperoleh informasi bahwa semakin banyak jumlah nutrient di dalam danau maka akan semakin banyak pula eceng gondok dan volume danau semakin kecil. Hal ini sesuai fakta bahwa nutrien merupakan makanan bagi eceng gondok sehingga tingkat pertumbuhan eceng gondok meningkat [14], [15]. Dampak banyaknya eceng gondok 
dapat dilihat juga pada volume danau yang ikut menyusut yang diakibatkan oleh naiknya jumlah eceng gondok yang berubah mejadi endapan ketika dia mati.

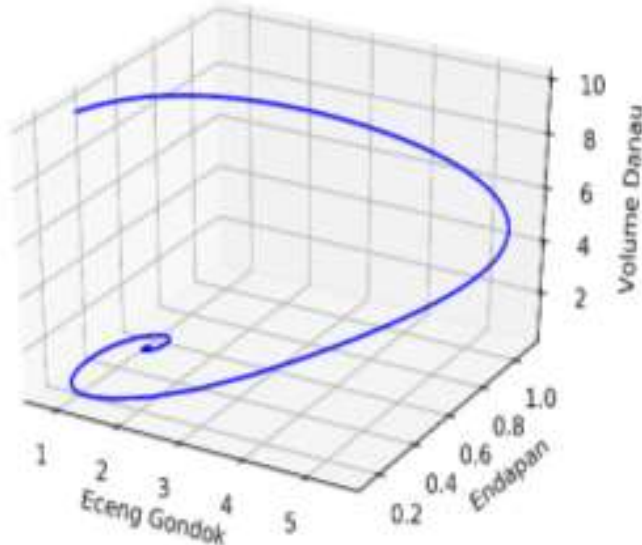

(Potret Fase)

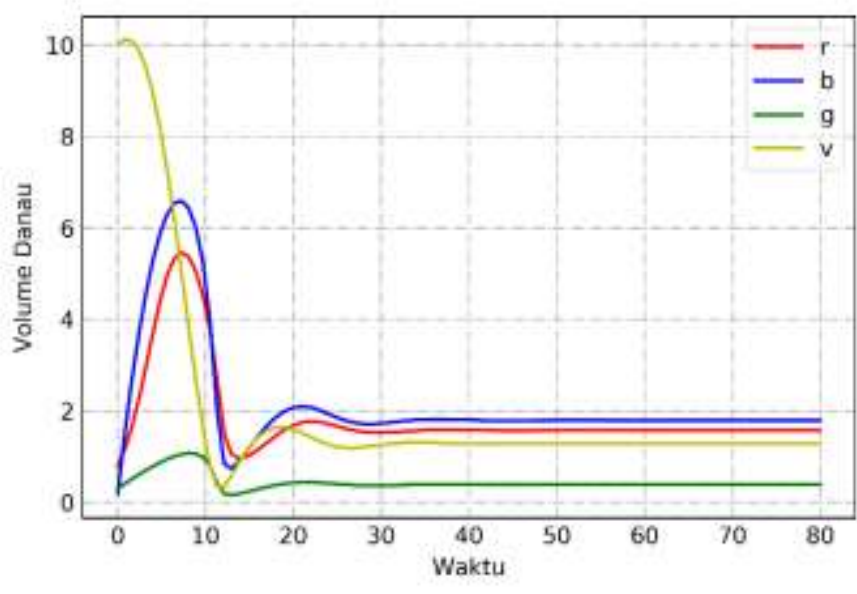

(Deret Waktu)

Gambar 3. Simulasi numerik model (1) menggunakan nilai parameter pada Tabel 3 dan $\kappa_{1}, \kappa_{2}, \kappa_{3}=0.5$

\section{Laju pengerukan endapan di danau $(\Lambda)$}

Pada tahap ini, simulasi dilakukan untuk melihat kondisi danau karena adanya revitalisasi berupa pengerukan endapan. Dengan menaikkan nilai $\Lambda$ dari 0.7 menjadi 2 maka terlihat dalam Gambar 1 dan Gambar 4 volume danau meningkat dari 1.2 menjadi 4.5. Hal ini menunjukkan bahwa semakin besar laju pengerukan pengerukan danau maka akan semakin besar pula volume danau. Artinya, jika pengerukan danau dilakukan dalam setiap periode waktu tertentu, maka hal ini dapat mempertahankan volume danau sehingga kondisi danau akan terhindar dari pendangkalan.

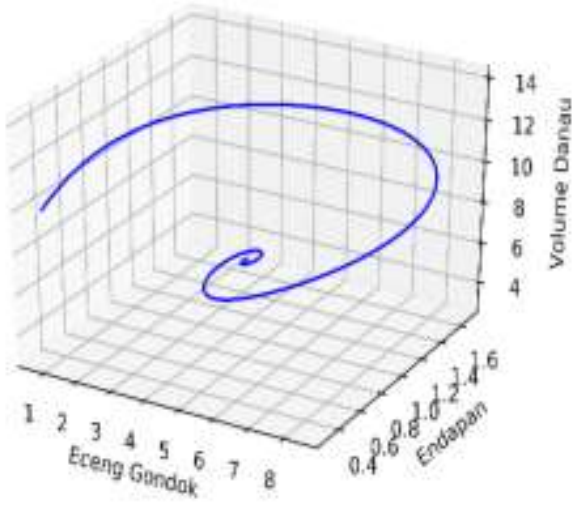

(Potret Fase)

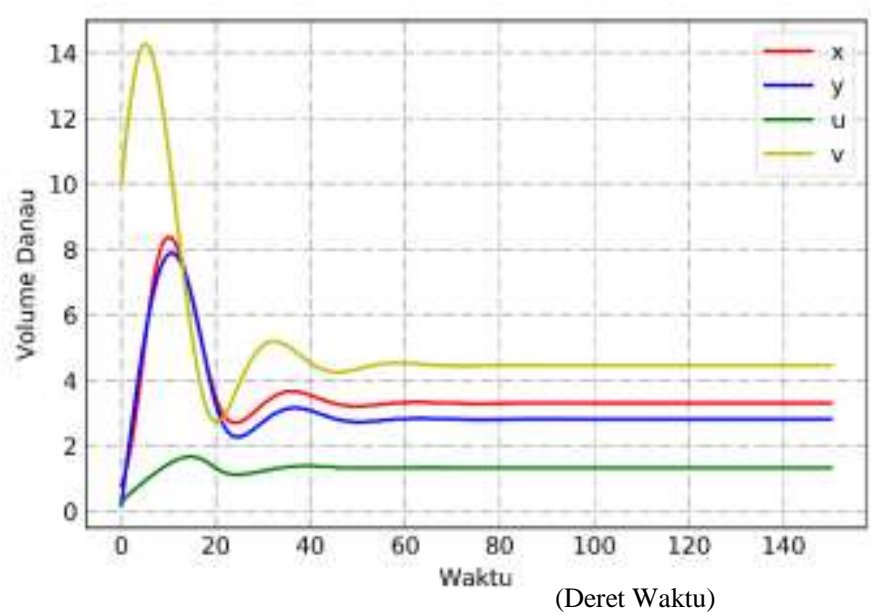

(Deret Waktu)

Gambar 4. Simulasi numerik model (1) menggunakan nilai parameter pada Tabel 3 dan $\Lambda=2$

\section{Laju pembersihan eceng gondok didanau $(H)$}

Simulasi ini dilakukan untuk melihat seberapa besar pengaruh dari pembersihan eceng gondok dalam menekan laju pendangkalan danau yang ditandai dengan bertambahnya volume danau. Berdasarkan Gambar 3, ketika parameter $H$ dinaikkan dari 0,2 menjadi 0,7 terlihat volume danau yang awalnya 1.8 menjadi 2.1. Hal ini menunjukkan bahwa dengan adanya pembersihan eceng gondok, maka volume danau juga akan semakin besar. Jika dibandingkan dengan solusi pengerukan endapan di simulasi sebelumnya, terlihat kenaikan/pertambahan volume danaunya tidak terlalu besar walaupun eceng gondok sudah habis dipermukaan danau. Hal ini disebabkan karena nutrient dan endapan yang berasal dari sungai masih ada di danau tersebut. Akan tetapi, ketika 
pembersihan eceng gondok di danau dilakukan secara kontinu maka hal ini dapat mempertahankan volume danau, sehingga eksistensi dari danau Limboto tetap terjaga.

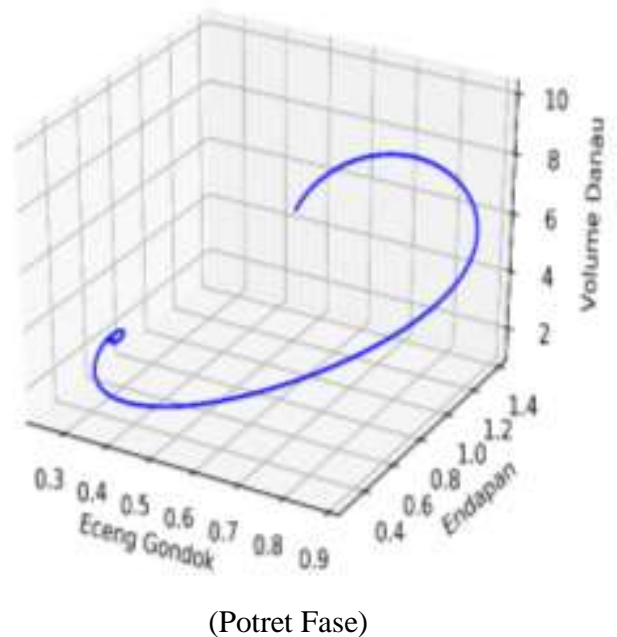

(Potret Fase)

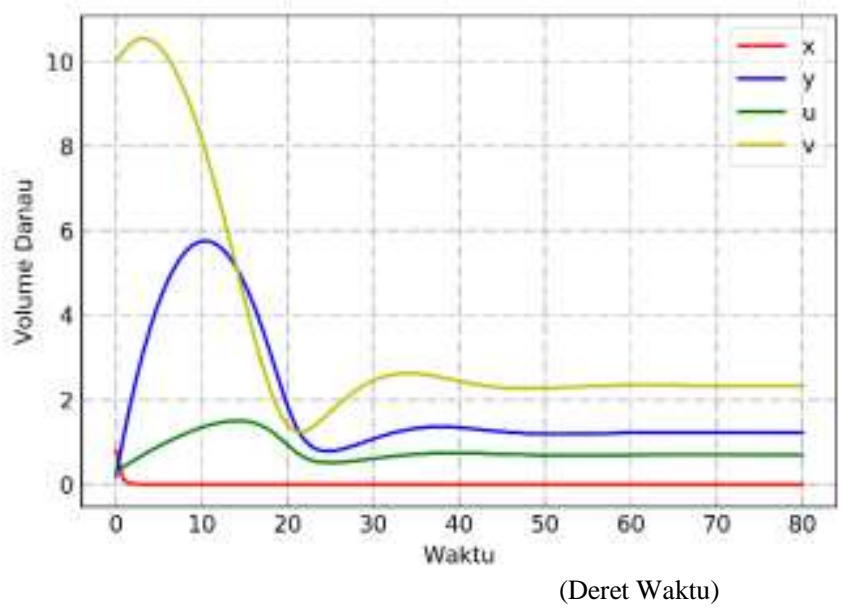

(Deret Waktu)

Gambar 5. Simulasi numerik model (1) menggunakan nilai parameter pada Tabel 3 dan $\mathbf{H}=0.7$

\section{KESIMPULAN}

Model matematika yang dituliskan dalam jurnal ini merupakan model modifikasi dengan menambahkan parameter pembersihan eceng gondok $(H)$ sebagai salah satu solusi dalam mencegah pendangkalan danau Limboto. Hasil yang diperoleh adalah dengan adanya pembersihan eceng gondok, maka kondisi danau akan terjaga eksistensinya yang ditandai dengan bertambahnya volume danau Limboto, meskipun tetap terjadi pengurangan volume akibat adanya endapan dan nutrien yang berasal dari sungai. Hal yang bisa dikembangkan lagi dalam penelitian ini adalah dengan menambahkan asumsi seperti membatasi limbah rumah tangga yang masuk, penebangan hutan secara ilegal, dan sebagainya.

\section{UCAPAN TERIMA KASIH}

Artikel ini merupakan hasil penelitian yang dibiayai dari dana PNBP Universitas Negeri Gorontalo tahun anggaran 2020 dengan nomor kontrak: B/47/UN47.D1/PT.01.03/2020.

\section{DAFTAR PUSTAKA}

[1] A. Nontji, DANAU-DANAU ALAMI NUSANTARA. Jakarta, 2016.

[2] R. dkk Akuba, "PROFIL DANAU LIMBOTO," 2009.

[3] I. Umar, A. Marsoyo, and B. Setiawan, "Analisis Perubahan Penggunaan Lahan Sekitar Danau Limboto Di Kabupaten Gorontalo," Tata Kota dan Drh., vol. 10, no. 2, pp. 77-90, 2018, doi: 10.21776/ub.takoda.2018.010.02.3.

[4] K. L. H. R. Indonesia, "Gerakan Penyelamatan danau (GERMADAN)," Gorontalo, 2015.

[5] R. Yunginger et al., "Lithogenic and anthropogenic components in surface sediments from lake limboto as shown by magnetic mineral characteristics, trace metals, and REE geochemistry," Geosci., vol. 8, no. 4, pp. 111, 2018, doi: 10.3390/geosciences8040116.

[6] S. S. P. Putri, Suryanti, "KONSENTRASI BAHAN ORGANIK PADA PROSES PEMBUSUKAN AKAR, BATANG DAN DAUN ECENG GONDOK (Eichhornia sp.) (SKALA LABORATORIUM)," J. MAQUARES, vol. 3, pp. 44-50, 2014.

[7] S. L. Mahmud, N. Achmad, and H. S. Panigoro, "Revitalisasi Danau Limboto dengan Pengerukan Endapan di Danau : Pemodelan, Analisis , dan Simulasinya," vol. 1, no. 1, pp. 31-40, 2020.

[8] A. Suryandari and Y. Sugianti, "Tumbuhan Air Di Danau Limboto, Gorontalo: Manfaat Dan Permasalahannya," BAWAL Widya Ris. Perikan. Tangkap, vol. 2, no. 4, p. 151, 2009, doi: 10.15578/bawal.2.4.2009.151-154.

[9] M. Ndii, PEMODELAN MATEMATIKA (Dinamika Populasi dan Penyebaran Penyakit), Satu. Yogyakarta: 
Deepublish, 2018.

[10] L. Perko, Differential Equations and Systems Dynamical, 3rd ed. New York: Springer, 2001.

[11] S. Wiggins, "Introduction to Applied Nonlinear Dynamical Systems \& Chaos." 1996.

[12] E. Nusantari, "KERUSAKAN DANAU LIMBOTO DAN UPAYA KONSERVASI MELALUI PEMBERDAYAAN MASYARAKAT DAN PERAN PERGURUAN TINGGI," J. Pendidik. Biol. UNM, vol. 1, no. Februari, 2010, doi: 10.1017/CBO9781107415324.004.

[13] A. K. M. A Amin, Y. I. Arifin, and N. Akase, "Studi Fasies Formasi Endapan Danau Untuk Menentukan Lingkungan Pengendapan Danau Limboto," Jambura Geosci. Rev., vol. 1, no. 2, pp. 50-67, 2019, doi: 10.34312/jgeosrev.v1i2.2056.

[14] F. Lihawa and M. Mahmud, "Evaluasi Karakteristik Kualitas Air Danau Limboto," J. Pengelolaan Sumberd. Alam dan Lingkung. (Journal Nat. Resour. Environ. Manag., vol. 7, no. 3, pp. 260-266, 2017, doi: 10.29244/jpsl.7.3.260-266.

[15] S. Yuningsih and M. Ngabito, "Water Pollution Level Of Limboto Lake Of Gorontalo," J. Fish. Progr. Stud. Perikan. dan Ilmu Kelautan, Univ. Gorontalo. Vol 1. No. 2 - 10 - 2018. P-ISSN 2614-1132, E-ISSN 2614-2856, vol. 1, no. 2, 2018. 
